\title{
Foliar mycoendophytome of an endemic plant of the Mediterranean biome (Myrtus communis) reveals the dominance of basidiomycete woody saprotrophs
}

\author{
Aline Bruna M Vaz ${ }^{1}$, Paula Luize C Fonseca ${ }^{1}$, Felipe F Silva ${ }^{2}$, Gabriel Quintanilha-Peixoto ${ }^{2}$, Inmaculada Sampedro \\ ${ }^{3}$, Jose A Siles ${ }^{3}$, Anderson Carmo ${ }^{4}$, Rodrigo B Kato ${ }^{2}$, Vasco Azevedo ${ }^{4}$, Fernanda Badotti ${ }^{5}$, Juan A Ocampo ${ }^{3}$, Carlos \\ A Rosa ${ }^{1}$, Aristóteles Góes-Neto ${ }^{\text {Corresp. } 1}$ \\ 1 Department of Microbiology, Universidade Federal de Minas Gerais, Belo Horizonte, Minas Gerais, Brazil \\ 2 Graduate Program of Bioinformatics, Universidade Federal de Minas Gerais, Belo Horizonte, Minas Gerais, Brazil \\ 3 Department of Soil Microbiology and Symbiotic Systems, Estación Experimental del Zaidín, C.S.I.C., Granada, Spain \\ 4 Department of Genetics, Ecology, and Evolution, Universidade Federal de Minas Gerais, Belo Horizonte, Minas Gerais, Brazil \\ 5 Department of Chemistry, Centro Federal de Educação Tecnológica de Minas Gerais, Belo Horizonte, Minas Gerais, Brazil \\ Corresponding Author: Aristóteles Góes-Neto \\ Email address: arigoesneto@icb.ufmg.br
}

The true myrtle, Myrtus communis, is a small perennial evergreen tree that occurs in Europe, Africa, and Asia with a circum-Mediterranean geographic distribution. Unfortunately, the Mediterranean Forests, where M. communis occurs, are critically endangered and are currently restricted to small fragmented areas in protected conservation units. In the present work, we performed, for the first time, a metabarcoding study on the spatial variation of fungal community structure in the foliar endophytome of this endemic plant of the Mediterranean biome, using bipartite network analysis as a model. The local bipartite network of Myrtus communis individuals and their foliar endophytic fungi is very low connected, with low nestedness, and moderately high specialization and modularity. Similar network patterns were also retrieved in both culturedependent and amplicon metagenomics of foliar endophytes in distinct arboreal hosts in varied biomes. Furthermore, the majority of putative fungal endophytes species were basidiomycote woody saprotrophs of the orders Polyporales, Agaricales, and Hymenochaetales. Altogether, these findings suggest a possible adaptation of these wooddecaying fungi to cope with moisture limitation and spatial scarcity of their primary substrate (dead wood), which are totally consistent with the predictions of the viaphytism hypothesis that wood-decomposing fungi inhabit the internal leaf tissue of forest trees in order to enhance dispersal to substrates on the forest floor, by using leaves as vectors and as refugia during periods of environmental stress. 


\title{
1 Foliar mycoendophytome of an endemic plant of the
} 2 Mediterranean biome (Myrtus communis) reveals the 3 dominance of basidiomycete woody saprotrophs

4

Aline Bruna Martim Vaz ${ }^{a}$, Paula Luize Camargos Fonseca ${ }^{a}$, Felipe Ferreira da Silva ${ }^{b}$, Gabriel Quintanilha-Peixoto ${ }^{b}$, Inmaculada Sampedro ${ }^{c}$, Jose A. Siles ${ }^{c}$, Anderson Carmo ${ }^{d}$, Rodrigo Bentes Kato $^{b}$, Vasco Azevedo ${ }^{a}$, Fernanda Badotti ${ }^{\mathrm{e}}$, Juan A. Ocampo ${ }^{\mathrm{c}}$, Carlos Augusto Rosa ${ }^{\mathrm{a}}$, Aristóteles Góes-Neto ${ }^{\text {a }}$

a Department of Microbiology, Universidade Federal de Minas Gerais Belo Horizonte, MG, Brazil.

${ }^{b}$ Graduate Program of Bioinformatics, Universidade Federal de Minas Gerais, Belo Horizonte, Minas Gerais, Brazil

${ }^{\mathrm{c}}$ Department of Soil Microbiology and Symbiotic Systems, Estación Experimental del Zaidín, C.S.I.C., Granada, Spain

${ }^{\mathrm{d}}$ Department of Genetics, Ecology, and Evolution, Universidade Federal de Minas Gerais, Belo Horizonte, MG, Brazil.

e Department of Chemistry, Centro Federal de Educação Tecnológica de Minas Gerais, Belo Horizonte, MG, 30480-000, Brazil.

* Corresponding author: Aristóteles Góes-Neto. Federal University of Minas Gerais, Institute of Biological Sciences. Av. Presidente Antônio Carlos, 6627, Pampulha, LBMCF, ICB, Bloco J4 sala 158, Pampulha, Belo Horizonte, MG, 31270-901, Brazil. Phone +55 31 3409-3050. E-mail: arigoesneto@icb.ufmg.br

\begin{abstract}
The true myrtle, Myrtus communis, is a small perennial evergreen tree that occurs in Europe, Africa, and Asia with a circum-Mediterranean geographic distribution. Unfortunately, the Mediterranean Forests, where M. communis occurs, are critically endangered and are currently restricted to small fragmented areas in protected conservation units. In the present work, we performed, for the first time, a metabarcoding study on the spatial variation of fungal community structure in the foliar endophytome of this endemic plant of the Mediterranean biome, using bipartite network analysis as a model. The local bipartite network of Myrtus communis individuals and their foliar endophytic fungi is very low connected, with low nestedness, and moderately high specialization and modularity. Similar network patterns were also retrieved in both culturedependent and amplicon metagenomics of foliar endophytes in distinct arboreal hosts in varied biomes. Furthermore, the majority of putative fungal endophytes species were basidiomycote woody saprotrophs of the orders Polyporales, Agaricales, and Hymenochaetales. Altogether, these findings suggest a possible adaptation of these wood-decaying fungi to cope with moisture limitation and spatial scarcity of their primary substrate (dead wood), which are totally consistent with the predictions of the viaphytism hypothesis that wood-decomposing fungi inhabit the internal leaf tissue of forest trees in order to enhance dispersal to substrates on the forest floor, by using leaves as vectors and as refugia during periods of environmental stress.
\end{abstract}

Keywords: fungal endophytes, myrtle, metabarcoding, community structure, bipartite networks. 


\section{Introduction}

Mediterranean Forests, Woodlands and Scrubs comprise a distinct biome of the Palearctic Biogeographic Realm (Olson et al., 2001). Amongst the distinct ecoregions of this biome, the Southwestern Mediterranean sclerophyllous and mixed forests ecoregion is characterized by old crystalline substrates, such as granite, quartzite, and marble, with hot and dry summers and relatively mild and humid winters (Olson et al., 2001). These forests are mainly composed of evergreen broadleaves trees and shrubs such oaks, true myrtle (Myrtus communis), laurel and even two endemic palms, which give a unique subtropical feature to these dry, warm coastal landscapes occurring all around the Mediterranean Sea (Regato, 2001). Unfortunately, nowadays, these forests, as well as others in the Mediterranean biome, are critically endangered and only remain in small, fragmented areas, such as protected conservation units in the distinct Mediterranean countries (Regato, 2001).

Myrtus communis, the true (or common) myrtle, is an evergreen perennial and sclerophyll shrub or small tree, usually 1.8-3.0 $\mathrm{m}$ in height, with dark green glossy, glabrous and coriaceous leaves, white flowers and blue-black berry fruits (Sumbul et al., 2011). It is a diploid plant, which is allogamous and self-compatible, whose fruits are mainly dispersed by birds and small mammals (Migliore et al., 2012). M. communis is the only species of the tribe Myrtae of the family Myrtaceae that occurs in Europe (Vasconcelos et al., 2017), with a typical circum-Mediterranean geographic distribution (Migliore et al., 2012).

Besides its extensive use in ethnomedicine for the treatment of disorders such as diarrhea, peptic ulcer, hemorrhoids, inflammation, pulmonary and skin diseases (Alipour et al., 2014), myrtle has also been used in food (liquors, meat, and sauces flavor) and cosmetic (perfumes) industries (Aleksic \& Knezevic, 2014). M. communis leaves are rich in terpenes, phenolic acids, tannins, and flavonoids, and its extracts exhibit high antibacterial activity (Aleksic \& Knezevic, 2014). Furthermore, myrtucommulones (a group of oligomeric nonprenylated acylphloroglucinols) reported from $M$. communis with potent antioxidant, anti-inflammatory, and antineoplastic properties, are also produced by a strain of fungal endophyte isolated from the phyllosphere of this endemic plant of the Mediterranean biome (Nicoletti et al., 2014).

The phyllosphere of land plants supports a great richness and abundance of microorganisms and, amongst them, fungal epiphytes and endophytes (Vorholt, 2012). Fungal endophytes are internal colonizers of aboveground tissues of plants and, apparently, do not cause any symptoms of diseases on their hosts (Skaltsas et al., 2019; Vaz et al., 2018). Moreover, visually healthy leaves contain numerous, independent infections, rather than systemic or otherwise extensive growth of hyphae (Arnold, 2008).

Fungal endophytes were first reported by the botanist Heinrich Friedrich Link still in the beginning of the 19th century (Hardoim et al., 2015); however, only since the 1970's (Carrol, 1978), 1980's (Carrol, 1988) and beginning of the 1990's (Petrini, 1991) that they have been more intensively studied. In a very recent and comprehensive review, Harrison and Griffin (2020) estimated that, among the 17 biomes of the Earth (Olsen et al., 2001), seven were understudied and together composed only $7 \%$ of the studies that were evaluated. One of these understudied biomes is the Mediterranean Forests, Woodlands and Scrubs, where the species Myrtus communis typically occurs. This aforementioned systematic review study also pointed out that that fungal endophyte diversity has already been characterized in, at least, one host from $30 \%$ of embryophyte families (Harrison and Griffin, 2020), including many species of Myrtaceae in the tribe Myrtae, 
88

89

90

91

92

93

94

95

96

97

98

99

100

101

102

103

104

105

106

107

108

109

110

111

112

113

114

115

116

117

118

119

120

121

122

123

124

125

126

127

128

129

130

131

132

133

such as Myrciaria floribunda, Eugenia aff. bimarginata (Vaz et al., 2012), Luma apiculata and Myrceugenia ovata var. nanophylla (Vaz, da Costa, et al., 2014; Vaz, Fontenla, et al., 2014).

Fungal endophytes are an omnipresent and phylogenetically diverse group of organisms that establish stable long-term interactions with their plant hosts (Rashmi et al., 2019). Furthermore, their impacts (either positive or negative) on the plants where they live at least part of their life cycle, may vary depending on the physiological status of the host, nutrient availability, environmental conditions and interaction with the microbiome and the plant host itself (Fesel Zuccaro 2016). The impact of fungal endophytes is usually considered as strongly contextdependent (Rodriguez et al., 2009), and the relationships between plant hosts and their fungal endophytes can range from mutualism through commensalism to latent or even mild antagonism (Saikkonen et al., 1998; Schulz and Boyle, 2005; Porras-Alfaro and Bayman, 2011). Therefore, many fungal endophytes can, in fact, be latent pathogens and latent saprotrophs (Hyde; Soytong, 2008).

Until quite recently, most of the studies on fungal endophytes are still based on a culturedependent approach (Christian et al., 2017). Nevertheless, methods based on culture are very selective and highly influenced by the composition of the culture media, the physiological adaptations of the fungi, and the sampling procedures, which influence the taxonomic composition, richness, and abundance of fungal endophytes recovered (Stone et al., 2004). Therefore, a metagenomics approach, based on the amplification of a taxonomic biomarker before massively parallel sequencing, theoretically provides a significantly more detailed access to the diversity of the mycobiome of any kind of substrate (Orellana, 2013), including the internal tissues of leaves in living plants (Vaz et al., 2017).

DNA metabarcoding is nowadays an essential tool in the methodological toolbox of fungal ecology, which has taken a monumental step forward since the advent of high-throughput DNA sequencing (Brown et al., 2018). To our knowledge, the first study of DNA metabarcoding of foliar fungal communities, which included fungal endophytes, was in the phyllosphere of Quercus macrocarpa, a native tree species occurring in temperate climate (Jumpponen; Jones, 2009). Afterwards, since other pioneering studies in the beginning of this decade (Zimmerman and Vitousek, 2012; Cordier et al., 2012), many metabarcoding studies of foliar fungal endophytes have been performed (Harrison and Griffin, 2020).

The rapidly developing theory of complex networks, based on graph theory, has been successfully applied to uncover the organizing principles governing the formation and evolution of several complex biological systems (Andrade et al., 2011; Góes-Neto et al., 2010). Bipartite interaction networks, which comprise interaction networks with two trophic levels, a lower and a higher, has been widely used to model two-level networks in Ecology, such as pollination and predator-prey (Dormann et al., 2009). Nonetheless, studies in natural ecosystems using DNA metabarcoding associated with bipartite interaction networks as a model to analyze foliar fungal endophytes-plant associations are still scarce (Barge et al., 2019; Cobian et al., 2019).

To date, as far as we know, there is no study investigating mycobiomes of Myrtus communis, the only European genus of Myrtaceae, using a metabarcoding approach modelled by bipartite networks. Additionally, the Mediterranean Forests, Woodlands and Scrubs, where $M$. communis is a bioindicator species, is one of understudied biomes of the world for fungal endophytes. Assuming the premises that (i) foliar endophytism may be an efficient strategy for saprotrophic fungi both as dispersal vehicle and as resource source during times of scarcity (Nelson et al., 2020) and (ii) a significant proportion of fungal endophytes of trees are saprotrophs (Parfitt et al., 2010), we hypothesize that, in biomes seasonally subjected to hydric deficiency, such as the 
134 Mediterranean biome, a high relative incidence and abundance of saprotrophic fungi will be

135 inhabiting tree hosts when compared to pathotrophic and symbiothrophic guilds. Thus, in the 136 current work, we performed, for the first time, a study on the spatial variation of fungal community 137 structure in the foliar endophytome of this endemic plant of the Mediterranean biome, and their

138 probable ecological functions in distinct individuals of this $M$. communis, using bipartite network 139 analysis as a model.

140

141 Materials \& Methods

\section{Study area}

143

144

145

146

147

Fieldwork was conducted in Sierra de Tejeda, Almijara y Alhama Natural Park. It is situated in the south of Andalusia, nearby the Mediterranean Sea, between Malaga and Granada provinces, and consists of several dolomitic mountain ranges. This park encompasses four distinct bioclimatic zones (thermo, meso, supra, and oromediterranean), with a wide variation in both mean annual temperature and rainfall, as well as elevation (Pérez Latorre et al., 2004).

\section{Sampling strategy and surface sterilization of the leaves}

Following a water stream downhill, we established a $100 \mathrm{~m}$ long transect along this stream (South-North direction). The initial point of the transect corresponded to the geographical coordinates $36^{\circ} 51^{\prime} 25^{\prime \prime} \mathrm{N} 03^{\circ} 41^{\prime} 40^{\prime \prime} \mathrm{W}$, with an elevation of approximately $360 \mathrm{~m}$, corresponding to a subhumid to semiarid thermomediterranean bioclimatic zone (Pérez Latorre et al., 2004). Besides Myrtus communis, the following plants were commonly encountered in the sampling site: Quercus suber, Quercus faginea, Smilax aspera, Pistacia lentiscus, Chamaerops humilis, Pteridium aquilinum, Brachypodium retusum, Dactylis hispanica, Phlomis purpurea, Rubus ulmifolius, and Cistus salvifolius (Pérez Latorre et al., 2004).

Five visually healthy leaves, with homogenous green coloration without any kind of discoloration or necrotic lesions, were collected from 11 visually healthy trees (without any observable signs or symptoms of diseases), which were approximately separated $1.0 \mathrm{~m}$ from each other in the transect. Afterwards, all the samples were maintained in individualized sterile plastic bags and refrigerated until the surface disinfection procedure. The leaves were rinsed under running tap water to remove dirt and debris, and, subsequently, disinfected by successive dipping in $70 \%$ ethanol $(1 \mathrm{~min}), 2 \%$ sodium hypochlorite $(3 \mathrm{~min})$, and sterile distilled water $(2 \mathrm{~min})$. Leaf fragments $\left(5 \mathrm{~mm}^{2}\right)$ were excised from each leave in six specific positions: one from the base near the petiole, two from the middle vein, one from the left margin, one from the right margin, and one from the apex (Saikkonen et al., 1998; Gamboa et al., 2003). All leaf fragments from each $M$. communis individual plants were then pooled and placed into 2-ml tubes with silica-gel in order to dehydrate and preserve the samples, and, thus, mitigating changes in the fungal diversity (Vaz et al., 2014).

\section{DNA extraction, amplification, and massively parallel sequencing}

Leaf samples were ground with liquid nitrogen and $300 \mathrm{mg}$ were used for genomic DNA extraction using the E.Z.N.A. ${ }^{\circledR}$ Plant DNA Kit Omega according to the manufacturer's instruction (Omega, Norcross, USA). The quality and quantity of DNA were evaluated using 
174 spectrophotometry (NanoDrop ND 1000, NanoDrop Technologies, Wilmington, USA). After the 175 extraction, the nuclear ribosomal internal transcribed spacer (ITS2) was amplified using the 176 primers fITS7 (Ihrmark et al., 2012) and ITS4 (White et al., 1990). PCR amplification was 177 performed using Kapa Taq DNA Polymerase High Fidelity Roche, Cape Town, South Africa) under the following conditions: 1 initial denaturation cycle at $94^{\circ} \mathrm{C}$ for $2 \mathrm{~min}$, followed by 35 denaturation cycles at $94^{\circ} \mathrm{C}$ for $1 \mathrm{~min}$, and annealing at $60^{\circ} \mathrm{C}$ for $1 \mathrm{~min}$, and extension at $72^{\circ} \mathrm{C}$ for $3 \mathrm{~min}$, with a final extension cycle at $72^{\circ} \mathrm{C}$ for $5 \mathrm{~min}$. At least three independent amplification reactions were performed from the same DNA extract. PCR products were then pooled in equimolar proportions based on their molecular weight and DNA concentrations, and purified using AMPure ${ }^{\circledR}$ Beads. The DNA was quantified using a fluorescence assay using Qubit ${ }^{\circledR} 2.0$ Fluorometer (Thermo) and Qubit® dsDNA BR Assay Kit (Thermo).

Sequencing libraries were generated using TrueSeq ${ }^{\circledR}$ DNA PCR-Free Sample Preparation Kit (Illumina, USA) following the manufacturer's recommendations and index codes were added. The library quality was assessed on the Qubit@2.0 Fluorometer (Thermo Scientific) and Bioanalyzer 2100 system (Agilent). The library was sequenced on a MiSeq platform (Illumina), and 2 x 250 bp paired-end reads were generated. All of the raw generated sequences were deposited in NCBI SRA under accession number PRJNA602325.

\section{Bioinformatic and ecological analyses}

The output files (FASTQ format) of the amplicon metagenomic sequencing of each one of the samples comprise our raw primary data. The bioinformatics pipeline (Supplementary Material 1) was elaborated and run on an Operational System Ubuntu 16.04.5 LTS system. The following programs were used: VSEARCH v2.9.1 (Rognes et al., 2016); BLAST v2.2.31+ (Camacho et al., 2009). Scripts in shell (McIlroy, 1987) and Python v3.0 (Martelli, 2006) programming languages were written to make some automatic tasks, such as merging samples or generating the abundance table. The reference database used for fungal taxonomic identification was UNITE v. 7.2 (Nilsson et al., 2010). The pipeline comprised the following steps, all of which using VSEARCH and BLASTn, as aforementioned: (i) quality and length filtering was done with VSEARCH removing sequences smaller than $300 \mathrm{bp}$ and default settings for quality filtering; (ii) dereplication was done

202

203

204

205

206

207

208

209

210

211

212

213

214

215

216

217 with VSEARCH; (iii) detection and removal of chimeric sequences using the UNITE database (uchime_reference_dataset_untrimmed.fasta) and de novo implementation by VSEARCH); (iv) clustering sequences with similarity above 97\% with VSEARCH; (v) automatic taxonomic identification with BLASTn was done in Python based in these rules, (Supplementary Material 2); and (vi) generation of the abundance table was built using python script (Supplementary Material $1)$.

Rows and columns within the interaction matrix represented distinct adult plant individuals of Myrtus communis (lower-level nodes) and fungal taxa (higher-level nodes), respectively. Each cell in the matrix comprised the number of reads of each fungal taxon in each $M$. communis individual. Therefore, the network was bipartite or two-mode in which nodes were divided in two disjoint sets and each link connected a node from one set (tree individuals) with a node from the other set (putative fungal species) (Fodor, 2020). In addition, the bipartite network was undirected, weighted, and quantitative. The R-package bipartite was used to visualize and plot the bipartite network and to calculate several network- and node- levels indices commonly used to describe patterns in bipartite ecological networks (Dormann et al., 2008) (Supplementary Material 3), and, specifically, MODULAR (Marquitti et al., 2014) was used to calculate the modularity (Q) by an 
218 annealing procedure to maximize Barber's modularity index (Barber, 2007). Moreover, classical

219

220

221

222

223

224

225

226

227

228

229

230

231

232

233

234

235

236

237

238

239

240

241

242

243

244

245

246

247

248

249

250

251

252

253

254

255

256

257

258

259

260

bipartite network representation was generated using Gephi 0.9.2 (Bastian et al., 2009).

The following aspects of network structure in both communitary and taxa levels were evaluated: connectance, nestedness, modularity, specialization, checkerboard score, and generality. As the bipartite network of foliar fungal endophytes and Myrtus communis individuals was quantitative, when possible, the indexes were calculated in their weighted counterpart, such as weighted connectance, weighted NODF, H2' specialization, proportional generality and species strength (Dormann et al., 2009). The communitary (network) indexes were analyzed to investigate if there are common structural patterns in the foliar fungal endophytes - Myrtus communis individuals that could be also encountered in other bipartite networks of fungal endophytes - plants (Mariani et al., 2019), while the taxon (node) level indices were analyzed to discover the most important, relevant or influential fungal endophyte taxa in the studied interaction (Marini et al., 2019).

Fungal taxa were functionally classified into three ecological trophic modes (saprotrophic, pathotrophic and symbiotrophic, or a combination of these), and the fungal guilds of each of these trophic modes, using the FunGuild database (Nguyen et al., 2016). As 11 fungal MOTUs (Molecular Operational Taxonomic Units) were not described in FunGuild, an extensive literature search was the strategy performed to describe the prevalent trophic mode of those MOTUs.

\section{Results}

The sequencing resulted in a total $621.9 \mathrm{Mb}$ with 212167 reads for a total of 11 samples. Table 1 shows the number of reads after each step in our metagenomic workflow.

\section{Network structure and fungal endophyte diversity}

The bipartite ecological network and corresponding adjacency matrix, comprising both the interactions between Myrtus communis individuals (lower trophic level) and the taxa of their foliar mycoendophytome (higher trophic level), are depicted in Figures 1 and 2, respectively. The network had order $(N)=56$ nodes and size $(M)=93$ edges. As it is a bipartite network, the lower level (LL) was composed of 11 Myrtus communis distinct individual plants, and the higher level (HL) encompassed 44 different fungal taxa (MOTUs), as identified by bioinformatics analyses, followed by an extensive manual curation. Excluding those assigned as undefined or incertae sedis, fungal endophyte MOTUs were classified into 44 putative species in 28 genera, 23 families, 16 orders, 11 classes, five subphyla and two phyla (Table 2). The phylum Basidiomycota, and, specifically, the subclass Agaricomycotina, the class Agaricomycetes and the orders Polyporales, Hymenochaetales and Agaricales were the most prevalent (relative MOTU richness) and the most frequent (relative read abundance) taxa in the higher trophic level (Table 2).

The bipartite network displayed an average of 1.7 links per node and an average linkage density of approximately 3.5 (Table 3 ). Weighted connectance was very low, nestedness (NODF, WNODF) was quite low, and modularity (Q) exhibited a medium value (Table 3 ). On the other hand, specialization (H2') and web asymmetry were moderately high (Table 3), mirrored in a high checkerboard score (C-score) of the higher trophic level (fungal endophytes).

The probability distribution of node degrees of the higher trophic level was very asymmetric. This asymmetry was reflected in a very high species strength of Aurantiporus sp.1, which occurred in all but one Myrtus communis individuals. Furthermore, Aurantiporus sp. 1 also displayed the highest weighted betweenness of all fungal taxa (Table 4), clearly showing the

PeerJ reviewing PDF | (2020:01:45197:3:0:NEW 24 Oct 2020) 
261

262

263

264

265

266

267

268

269

270

271

272

273

274

275

276

\section{7}

278

279

280

281

282

283

284

285

286

287

288

289

290

291

292

293

294

295

296

297

298

299

300

301

302

centrality and the importance of this fungal endophyte taxon in the network. Besides Aurantiporus sp., two other putative fungal species, Polyporaceae sp.1 and Polyporaceae sp.2, also exhibited a high proportional generality (Table 4), and the three MOTUs co-occurred in most of the sampled Myrtus communis individuals. Conversely, approximately $67 \%$ of putative species of foliar fungal endophytes displayed a very low value of proportional generality and, therefore, were qualitatively and quantitatively restricted to only one tree. Taken together, these results reinforced, even more, the asymmetric pattern of the higher-level taxa.

In lower trophic level (Myrtus communis individuals), the probability distribution of node degrees was much less asymmetric than in the higher trophic level (fungal endophytes), directly reflecting in a lower checkerboard score (C-score) and in a much higher niche overlap than those retrieved for the higher trophic level (Table 5). Apparently, there was no association between the distance of the sampled trees and their corresponding foliar endophytic fungi community since trees occurring more distantly were as similar as those that were nearer (e.g.: trees no. 3, 10, and 11). Additionally, the trees that usually displayed the highest values of species strength and effective partners also exhibited the highest values of proportional generality (with few exceptions) (Table 5).

\section{Fungal endophyte trophic modes and guilds}

The majority of putative fungal endophytes species (64.4\%) were assigned to the class Agaricomycetes (Basidiomycota) (Table 2), and, except for the genus Ceratobasidium, all the other genera of detected Agaricomycetes, notably of the orders Polyporales, Agaricales, and Hymenochaetales were assigned as woody saprotrophs (Table 6). Moreover, a third of all other putative endophytic fungal taxa of other classes, regardless of pertaining to Basidiomycota or Ascomycota, generally showed a saprotrophic nutrition mode, which is mainly related to wood decomposition (Table 6). Altogether, the great majority of endophyte taxa in Myrtus communis foliar mycoendophytome comprised saprotrophs, and especially, woody saprotrophs (Figure 3).

Approximately $36 \%$ of all fungal taxa were associated with pathotrophy either exclusively or in combination with saprotrophic (or, very rarely, symbiotrophic) nutrition mode due to less inclusive taxonomic assignment (Figure 3). Pathotrophic fungal taxa were primarily related to the plant pathology guild; however, pathotrophy might be linked to animal pathogens, especially for the ascomycetous and basidiomycetous yeasts (e.g.: Candida and Malassezia, respectively) (Table 6). In addition, exclusively symbiotrophic fungal endophytes were restricted to only one taxon (Figure 3).

\section{Discussion}

This study modeled the fungal endophyte community diversity in leaves of Myrtus communis individuals as a bipartite ecological network. In this kind of network, every member of one trophic level is only connected to the members of the other trophic level, so that the interactions within trophic levels (lower or higher) are not represented for the sake of simplicity (Dormann et al., 2008). Although using bipartite networks as a model to study animal-plant interactions is rather common (Dormann et al., 2009), studies specifically with endophytic fungi and their host plants are still quite rare (Toju et al., 2014). 
303

304

305

306

307

308

309

310

311

312

313

314

315

316

317

318

319

320

321

322

323

324

325

326

327

328

329

330

331

332

333

334

335

336

337

338

339

340

341

342

343

344

345

346

347

348

The local bipartite network of Myrtus communis individuals and their foliar endophytic fungi is very low connected, with low nestedness, and moderately high specialization and modularity. Connectance is a commonly used indicator of complexity at network level, and it intuitively accounts for the probability that any pair of taxa interact in the network (Landi et al., 2018). In our M. communis individuals / endophytic fungi bipartite network, the connectance (which is a qualitative index) as well as its quantitative counterpart, weighted connectance, were low as well as other network level index measuring complexity, the nestedness and weighted nestedness. Connectance and nestedness are positively correlated (Almeida-Neto, 2008), and the low values retrieved in our bipartite network ecologically means that the great majority of fungal endophytes species occur in only one or very few M. communis individuals, and, conversely, very few fungal species occur in many plant individuals. This is clearly corroborated by not only the moderately high values of the network-level indexes of specialization (H2') and checkerboard score (C-score), but also the node-level indexes of node and normalized degree, and effective partners and proportional generality. Furthermore, as there was no association between the distance of the sampled trees and their corresponding foliar fungal endophytes community and the environmental conditions are quite the same in sampling area, tree distance most probably serves or as proxy for dispersal limitation or this pattern occurs due to priority effects, and, therefore, are stochastic environmental drivers (Amend et al., 2019)

In spite of having worked with culture-dependent foliar endophytic fungal communities along with distinct North-American biomes, Chagnon et al. (2016) approximately retrieved these same network-level patterns. Furthermore, (Yao et al., 2019), working on metabarcoding-analyzed endophytic fungal communities associated with the leaves of six mangrove species, observed that endophytic network structure was characterized by significantly highly specialized and modular but lowly connected and anti-nested properties. Altogether, these similar findings pointed to possible common network-level patterns of foliar fungal endophyte communities in arboreous plants around the world.

The mycoendophytome of Myrtus communis individuals was, both qualitatively and quantitatively, mainly composed of basidiomycete fungi. Although there is a strong dominance of species of the phylum Ascomycota in culture-dependent methods (Rashmi et al., 2019), this scenario drastically changed after the publishing of data originated from culture-independent and, more specifically, metabarcoding studies (Yao et al., 2019). These differences were mainly observed in the abundance of the commonly isolated genera and may be related to the ability of certain genera to grow readily on artificial media and overgrow other fungi (Skaltsas et al., 2019). Isolation of Basidiomycota in typical culture-based approaches, for instance, is challenging as they usually do not grow or develop slowly and are rapidly outcompeted by ascomycete species (Martin et al., 2015).

Although it is native of the Mediterranean biome, M. communis is a species cultivated worldwide for its medicinal uses (Sumbul et al., 2011). Therefore, different research articles have studied its relationships with fungi, many of which are found in the USDA fungal-host database, which keeps records for M. communis as early as 1941 (Unamuno, 1941), especially directly observable phytopathogenic fungi that were reported in that plant species. After revising the synonymy, using both Mycobank (http://www.mycobank.org/) and IndexFungorum (http://www.indexfungorum.org/) databases, there are 15 fungal species associated with Myrtus communis in their original region of occurrence, the Mediterranean biome, in the USDA FungusHost database. Furthermore, some of them are indeed basidiomycete woody saprothrophs, such as Antrodia albida and Stereum reflexulum. In our study, there are some taxa such as Polyporaceae 
349

350

351

352

353

354

355

356

357

358

359

360

361

362

363

364

365

366

367

368

369

370

371

372

373

374

375

376

377

378

379

380

381

382

383

384

385

386

387

388

389

390

391

392

393

sp.1 / Polyporaceae sp.2 and Thelephorales sp. that could represent, for instance, a possible Antrodia and Stereum (such as cited in USDA fungus-host database), respectively, but we did not have a more inclusive and reliable taxonomic identification beyond family level. More recent studies, such as that of Nicoletti et al. (2014) reinforce the relationship between plant metabolism and fungal species content. Nonetheless, the common thread among all of those studies is the methodology, which is culture-dependent. It is well-known that those methods are contextdependent and highly influenced by the culture medium composition (Stone et al., 2004), as well as by the fact that most of the microorganisms, including the fungi, are still unculturable using contemporary methods (Hongoh, 2011; Salvioli et al., 2008). Therefore, culture-dependent methods might be appropriate for single species-driven research, but highly underestimate taxonomic composition, richness, and abundance as in modern diversity studies (Stefani et al., 2015), which are conceivable using culture-independent high-throughput sequencing methods, such as the ones employed in our study. Although amplicon metagenomics is a large-scale, rapid, and independent of culturing and/or direct observation, as any method, there may also be biases, such as in the initial amplicon library preparation, differential primer annealing, PCR and sequencing artifacts, and contig assembly (Brooks et al, 2015; Nilsson et al., 2015). Both methods; however, are complementary, and when possible, is very advantageous to use them in an integrative manner, especially to solve problems of species-level identification.

The Polyporales were, by far, the most prevalent and frequent foliar fungal endophytes of Myrtus communis, and, along with Hymenochaetales and Agaricales, accounted for $55.5 \%$ of all the putative endophytic fungi species. Even using a culture-based approach, in a study on a huge collection of native Hevea brasiliensis fungal endophytes, Martin et al. (2015) pointed out that $75 \%$ of all basidiomycete endophytes of this hyperdiverse tree of Amazon Forest encompassed species of the order Polyporales. In addition, Hymenochaetales and Agaricales also corresponded to a significant proportion of basidiomycete endophytes of the rubber tree (Martin et al., 2015).

Although it is not possible to state if there are any potential ecological benefit of these dominant wood-decomposing basidiomycete endophytes for $M$. communis, there are many reports in specialized literature accounting for positive impacts of fungal endophytes on their hosts, such as resistance to pathogens, herbivores, and abiotic stresses (Delaye et al., 2013). Nonetheless, the result of these interactions is highly context-dependent (Saikkonen et al. 2010). Amongst the Polyporales, the taxon Aurantiporus sp.1 dominated the foliar mycoendophytome of Myrtus communis. The genus Aurantiporus is rarely reported as an endophyte (Dastogeer et al., 2017) and comprises woody decomposers that produce white rot in their hosts and is frequently encountered in dead wood of angiosperms (He et al., 2019; Zmitrovich, 2018). Aurantiporus sp.1 is very closely related to Aurantiporus sp. KT156705, whose complete ITS sequence was derived from fieldcollected basidiomata on dead wood in Costa Rica, which, in turn, is more phylogenetically related to Aurantiporus pulcherrimus than any other species of the genus Aurantiporus (Papp \& Dima, 2018). Nonetheless, multigene phylogenetic analyses showed that this genus has a polyphyletic origin, and, thus, a more detailed study is certainly required (Papp \& Dima, 2018). Therefore, it is even possible that Aurantiporus sp.1 be a new species in this poorly studied genus.

As well as Aurantiporus sp.1, the great majority of the putative species of foliar fungal endophytes of Myrtus communis are saprotrophs, especially wood decayers, and a significant proportion was also categorized as pathotrophs. Actually, there is compelling evidence that endophytes could act as latent saprotrophs or latent pathogens (Fesel \& Zuccaro, 2016; PorrasAlfaro \& Bayman, 2011; Schulz \& Boyle, 2005; Sieber, 2007). Thus, many foliar fungal 
394

395

396

397

398

399

400

401

402

403

404

405

406

407

408

409

410

411

412

\section{Conclusions}

414

415

416

417

418

419

420

421

422

423

424

425

426

427

428

429

\section{0}

431

432

433

endophytes would invade plant hosts either by leaf or even shoot surfaces and using, in the latter case, a sapwood route of infection (Martin et al., 2015; Parfitt et al., 2010).

Although the Foraging Ascomycete (FA) hypothesis was originally proposed more than 20 years ago (Carroll, 1999), it has only been tested quite recently, using the genus Xylaria in a tropical cloud forest site as a case study (Thomas et al., 2016). This hypothesis states that, for wood-degrading fungi, endophytism is a life-history strategy to span the scarcity of dead wood substrates and stressful environmental conditions, such as hydric restriction, in both time and space (Carroll, 1999; Thomas et al., 2016). Despite this FA hypothesis having been initially suggested for Ascomycota (Caroll, 1999), in fact, it can be applied to any endophytic fungus regardless of its taxonomic assignment, and the term viaphytism has been recently proposed (Nelson et al., 2020). The Viaphytism hypothesis states that many fungi may be in a continuous and cyclical flux between life stages as endophytes in the forest canopy and as wood-decomposing fungi on the forest floor (Thomas et al., 2020). Therefore, this cycle can really be a very common and still previously ignored ecological process in forests, which may have far-reaching implications for whole forest health (Thomas et al., 2020). Thus, the dominance of basidiomycete woody saprothrophs in the foliar mycoendophytome of Myrtus communis in Southwestern Mediterranean sclerophyllous forest may be a possible adaptation of these wood-decaying fungi to cope with moisture limitation and spatial scarcity of their primary substrate (dead wood), which are totally consistent with the predictions of viaphytism hypothesis (Nelson et al., 2020; Thomas et al., 2020).

In conclusion, we carried out, for the first time, an amplicon (nrITS) metagenomic study on the spatial variation of the foliar mycoendophytome of Myrtus communis, an endemic tree of the Mediterranean biome, using, as a model, bipartite network analysis. The bipartite network of the trees and their foliar fungal endophytes was very low connected, and displayed low nestedness, and moderately high specialization and modularity. Similar communitary (network) patterns were also retrieved in both culture-dependent and metabarcoding of foliar endophytic fungi in distinct arboreal hosts in diverse biomes. Moreover, most of the putative endophytic fungi species were basidiomycete woody saprotrophs of the orders Polyporales, Agaricales, and Hymenochaetales. Taking together, our findings corroborate the viaphytism hypothesis (Nelson et al., 2020; Thomas et al., 2020), which states that saprotrophic fungi (especially the wood decayers) can utilize leaves both as dispersal vehicles and as resource during times of scarcity (Nelson et al., 2020). Furthermore, as the viaphytism hypothesis have been tested only in trees in humid biomes (rainforests) without any marked seasonal hydric deficiency (Thomas et al. 2016; Thomas et al., 2019), our study not only corroborate the viaphytism hypothesis but also extended it to a typical and endemic tree in Mediterranean biome, which is characterized by a dry and hot summer season that is very unfavourable to wood-decomposing fungi.

\section{Acknowledgements}

The authors wish to thank Rafael León Morcillo to take the samples and Daniel Santana de Carvalho and Eric Roberto Guimarães Rocha Aguiar for helping with statistical analysis and image editing. The authors would also like to thank the Graduate Programs of Microbiology

Peer) reviewing PDF | (2020:01:45197:3:0:NEW 24 Oct 2020) 
434 (http://www.microbiologia.icb.ufmg.br/pos/)

and

Bioinformatics

435 (http://www.pgbioinfo.icb.ufmg.br) of the Universidade Federal de Minas Gerais.

\section{References}

437

438

439

440

441

442

443

444

445

446

447

448

449

450

451

452

453

454

455

456

457

458

459

460

461

462

463

464

465

466

467

468

469

470

471
Aleksic, V., \& Knezevic, P. (2014). Antimicrobial and antioxidative activity of extracts and essential oils of Myrtus communis L. Microbiological Research, 169(4), 240-254. https://doi.org/10.1016/j.micres.2013.10.003

Alipour, G., Dashti, S., \& Hosseinzadeh, H. (2014). Review of pharmacological effects of Myrtus communis L. and its active constituents. Phytotherapy Research, 28(8), 1125-1136. https://doi.org/10.1002/ptr.5122

Andrade, R. F. S., Rocha-Neto, I. C., Santos, L. B. L., de Santana, C. N., Diniz, M. V. C., Lobão, T. P., Goés-Neto, A., Pinho, S. T. R., \& El-Hani, C. N. (2011). Detecting Network Communities: An Application to Phylogenetic Analysis. PLoS Computational Biology, 7(5). https://doi.org/10.1371/journal.pcbi.1001131

Arnold, A. E. (2008). Endophytic fungi: hidden components of tropical community ecology. Tropical Forest Community Ecology, 178-188.

Barber, M. J. (2007). Modularity and community detection in bipartite networks. Physical Review E - Statistical, Nonlinear, and Soft Matter Physics, 76(6), 1-9. https://doi.org/10.1103/PhysRevE.76.066102

Barge, E. G., Leopold, D. R., Peay, K. G., Newcombe, G., \& Busby, P. E. (2019). Differentiating spatial from environmental effects on foliar fungal communities of Populus trichocarpa. Journal of Biogeography, 46(9), 2001-2011. https://doi.org/10.1111/jbi.13641

Bastian, M., \& Heymann, S. (2009). Gephi: An Open Source Software for Exploring and Manipulating Networks. Proceedings of the Third International ICWSM Conference, 361362.

Brooks JP, Edwards DJ, Harwich MD, Rivera MC, Fettweis JM, Serrano MG, Reris RA, Sheth NU, Huang B, Girerd P, Strauss JF. (2015). The truth about metagenomics: quantifying and counteracting bias in 16S rRNA studies. BMC Microbiology, 15(1):1-4. https://doi.org/10.1186/s12866-015-0351-6

Brown, S. P., Leopold, D. R., \& Busby, P. E. (2018). Protocols for Investigating the Leaf Mycobiome Using High-Throughput DNA Sequencing. Methods, 1848, 39-51. https://doi.org/10.1007/978-1-4939-8724-5

Camacho, C., Coulouris, G., Avagyan, V., Ma, N., Papadopoulos, J., Bealer, K., \& Madden, T. L. (2009). BLAST+: architecture and applications. BMC Bioinformatics, 10, 1-9. https://doi.org/10.1186/1471-2105-10-421

Carroll, G. (1988). Fungal endophytes in stems and leaves: from latent pathogen to mutualistic symbiont. Ecology, 69(1), 2-9.

Carroll, G C. (1999). The foraging ascomycete. 16th International Botanical Congress, St. Louis, MO, USA, 1999. 
472

473

474

475

476

477

478

479

480

481

482

483

484

485

486

487

488

489

490

491

492

493

494

495

496

497

498

499

500

501

502

503

504

505

506

507

508

509

510

511

Carroll, George C, \& Carroll, F. E. (1978). Studies on the incidence of coniferous needle endophytes in the Pacific Northwest. Canadian Journal of Botany, 56, 3034-3043.

Chagnon, P. L., U'Ren, J. M., Miadlikowska, J., Lutzoni, F., \& Elizabeth Arnold, A. (2016). Interaction type influences ecological network structure more than local abiotic conditions: evidence from endophytic and endolichenic fungi at a continental scale. Oecologia, 180(1), 181-191. https://doi.org/10.1007/s00442-015-3457-5

Christian, N., Whitaker, B. K., \& Clay, K. (2017). 5 CHAPTER A Novel Framework for Decoding Fungal Endophyte Diversity. The Fungal Community: Its Organization and Role in the Ecosystem, 65.

Cobian, G. M., Egan, C., \& Amend, A. S. (2019). Plant-microbe specificity varies as a function of elevation Gerald. BioRxiv, 1-30.

Dastogeer, K. M. G., Li, H., Sivasithamparam, K., Jones, M. G. K., \& Wylie, S. J. (2017). A simple and rapid in vitro test for large-scale screening of fungal endophytes from drought-adapted Australian wild plants for conferring water deprivation tolerance and growth promotion in Nicotiana benthamiana seedlings. Archives of Microbiology, 199(10), 1357-1370. https://doi.org/10.1007/s00203-017-1411-0

Delaye, L., García-Guzmán, G. and Heil, M., 2013. Endophytes versus biotrophic and necrotrophic pathogens - are fungal lifestyles evolutionarily stable traits?. Fungal Diversity, 60(1), pp.125-135. https://doi.org/ 10.1007/s 13225-013-0240-y

Dormann, C. F., Frund, J., Bluthgen, N., \& Gruber, B. (2009). Indices, Graphs and Null Models: Analyzing Bipartite Ecological Networks. The Open Ecology Journal, 2(1), 7-24. https://doi.org/10.2174/1874213000902010007

Dormann, C., Gruber, B., \& Fründ, J. (2008). Introducing the bipartite package: analysing ecological networks. Interaction, 1 (October), 0.2413793.

Fesel, P. H., \& Zuccaro, A. (2016). Dissecting endophytic lifestyle along the parasitism/mutualism continuum in Arabidopsis. Current Opinion in Microbiology, 32, 103-112. https://doi.org/10.1016/j.mib.2016.05.008

Fodor, E. (2020). Summary bipartite networks: trees in Romanian forests--wood pathogenic and sapro-pathogenic fungi. Journal of Plant Pathology, 102(1), 89-102.

Gamboa, M. A., Laureano, S., \& Bayman, P. (2003). Measuring diversity of endophytic fungi in leaf fragments: Does size matter? Mycopathologia, 156(1), 41-45.

https://doi.org/10.1023/A:1021362217723

Góes-Neto, A., Diniz, M. V. C., Santos, L. B. L., Pinho, S. T. R., Miranda, J. G. V., Lobao, T. P., Borges, E. P., El-Hani, C. N., \& Andrade, R. F. S. (2010). Comparative protein analysis of the chitin metabolic pathway in extant organisms: A complex network approach. BioSystems, 101(1), 59-66. https://doi.org/10.1016/j.biosystems.2010.04.006

Hardoim, P. R., van Overbeek, L. S., Berg, G., Pirttilä, A. M., Compant, S., Campisano, A., Döring, M., \& Sessitsch, A. (2015). The Hidden World within Plants: Ecological and Evolutionary Considerations for Defining Functioning of Microbial Endophytes. Microbiology and Molecular Biology Reviews, 79(3), 293-320. 
513

514

515

516

517

518

519

520

521

522

523

524

525

526

527

528

529

530

531

532

533

534

535

536

537

538

539

540

541

542

543

544

545

546

547

548

549

550
Harrison, J. G., \& Griffin, E. A. (2020). The diversity and distribution of endophytes across biomes, plant phylogeny and host tissues: how far have we come and where do we go from here? Environmental Microbiology, 00. https://doi.org/10.1111/1462-2920.14968

He, M.-Q., Zhao, R.-L., Hyde, K. D., Begerow, D., Kemler, M., Yurkov, A., McKenzie, E. H. C., Raspé, O., Kakishima, M., Sánchez-Ramírez, S., Vellinga, E. C., Halling, R., Papp, V., Zmitrovich, I. V., Buyck, B., Ertz, D., Wijayawardene, N. N., Cui, B.-K., Schoutteten, N., ... Kirk, P. M. (2019). Notes, outline and divergence times of Basidiomycota. Fungal Diversity, 99, 105-367. https://doi.org/10.1007/s13225-019-00435-4

Hyde, K. D., \& Soytong, K. (2008). The fungal endophyte dilemma. Fungal Diversity, 33, $163-173$.

Ihrmark, K., Bödeker, I. T. M. M., Cruz-Martinez, K., Friberg, H., Kubartova, A., Schenck, J., Strid, Y., Stenlid, J., Brandström-Durling, M., Clemmensen, K. E., \& Lindahl, B. D. (2012). New primers to amplify the fungal ITS2 region - evaluation by 454-sequencing of artificial and natural communities. FEMS Microbiology Ecology, 82(3), 666-677. https://doi.org/10.1111/j.1574-6941.2012.01437.x

Jumpponen, A., \& Jones, K. L. (2009). Massively parallel 454 sequencing indicates hyperdiverse fungal communities in temperate Quercus macrocarpa phyllosphere. New Phytologist, 184(2), 438-448. https://doi.org/10.1111/j.1469-8137.2009.02990.x

Mariani, M. S., Ren, Z. M., Bascompte, J., \& Tessone, C. J. (2019). Nestedness in complex networks: Observation, emergence, and implications. Physics Reports, 813, 1-90. https://doi.org/10.1016/j.physrep.2019.04.001

Marini, L., Bartomeus, I., Rader, R., \& Lami, F. (2019). Species-habitat networks: A tool to improve landscape management for conservation. Journal of Applied Ecology, 56(4), 923928. https://doi.org/10.1111/1365-2664.13337

Marquitti, F. M. D., Guimarães, P. R., Pires, M. M., \& Bittencourt, L. F. (2014).

MODULAR: Software for the autonomous computation of modularity in large network sets. Ecography, 37(3), 221-224. https://doi.org/10.1111/j.1600-0587.2013.00506.x

Martin, R., Gazis, R., Skaltsas, D., Chaverri, P., \& Hibbett, D. (2015). Unexpected diversity of basidiomycetous endophytes in sapwood and leaves of Hevea. Mycologia, 107(2), 284297. https://doi.org/10.3852/14-206

McIlroy, M. D. (1987). A Research UNIX Reader: Annotated Excerpts from the Programmer's Manual, 1971-1986. AT and T Bell Laboratories. Computing Science.

Migliore, J., Baumel, A., Juin, M., \& Médail, F. (2012). From Mediterranean shores to central Saharan mountains: Key phylogeographical insights from the genus Myrtus. Journal of Biogeography, 39(5), 942-956. https://doi.org/10.1111/j.1365-2699.2011.02646.x

Nelson A, Vandegrift R, Carroll GC, Roy BA. 2020. Double lives: transfer of fungal endophytes from leaves to woody substrates. PeerJ 8:e9341. https://doi.org/10.7717/peerj.9341

Nilsson, R. H. et al. A comprehensive, automatically updated fungal ITS sequence dataset 
551

552

553

554

555

556

557

558

559

560

561

562

563

564

565

566

567

568

569

570

571

572

573

574

575

576

577

578

579

580

581

582

583

584

585

586

587

588

589

590

for reference-based chimera control in environmental sequencing efforts. Microbes and environments 30, 145-150 (2015).

Nguyen, N. H., Song, Z., Bates, S. T., Branco, S., Tedersoo, L., Menke, J., Schilling, J. S., $\&$ Kennedy, P. G. (2016). FUNGuild: An open annotation tool for parsing fungal community datasets by ecological guild. Fungal Ecology, 20, 241-248. https://doi.org/10.1016/j.funeco.2015.06.006

Nicoletti, R., Ferranti, P., Caira, S., Misso, G., Castellano, M., Di Lorenzo, G., \& Caraglia, M. (2014). Myrtucommulone production by a strain of Neofusicoccum australe endophytic in myrtle (Myrtus communis). World Journal of Microbiology and Biotechnology, 30(3), 1047-1052. https://doi.org/10.1007/s11274-013-1523-x

Nilsson, R., Larsson, K.-H., Taylor, A., Bengtsson-Palme, J., Jeppesen, T., Schigel, D., Kennedy, P., Picard, K., Glöckner, F., Tedersoo, L., Saar, I., Kõljalg, U., \& Abarenkov, K. (2010). The UNITE database for molecular identification of fungi - recent updates and future perspectives. New Phytologist, 186, 281-285. https://doi.org/10.1111/nph.12154

Olson, D. M., DINERSTEIN, E., WIKRAMANAYAKE, E. D., BURGESS, N. D., POWELL, G. V. N., UNDERWOOD, E. C., D'AMICO, J. A., ITOUA, I., STRAND, H. E., MORRISON, J. C., LOUCKS, C. J., ALLNUTT, T. F., RICKETTS, T. H., KURA, Y., LAMOREUX, J. F., WETTENGEL, W. W., HEDAO, P., \& KASSEM, K. R. (2001). Terrestrial Ecoregions of the World: A New Map of Life on Earth. BioScience, 51(11), 933-938.

Orellana, S. C. (2013). Assessment of Fungal Diversity in the Environment using Metagenomics:a Decade in Review. Fungal Genomics \& Biology, 03(02). https://doi.org/10.4172/2165-8056.1000110

Papp, V., \& Dima, B. (2018). New systematic position of Aurantiporus alborubescens (Meruliaceae, Basidiomycota), a threatened old-growth forest polypore. Mycological Progress, 17(3), 319-332. https://doi.org/10.1007/s11557-017-1356-3

Parfitt, D., Hunt, J., Dockrell, D., Rogers, H. J., \& Boddy, L. (2010). Do all trees carry the seeds of their own destruction? PCR reveals numerous wood decay fungi latently present in sapwood of a wide range of angiosperm trees. Fungal Ecology, 3(4), 338-346. https://doi.org/10.1016/j.funeco.2010.02.001

Pérez Latorre, A., NAVAS FERNÁNDEZ, D., GAVIRA, O., CABALLERO, G., \& CABEZUDO, B. (2004). Vegetación del Parque Natural de las Sierras Tejeda, Almijara y Alhama (Málaga-Granada, España). Acta Botánica Malacitana, 29, 117-190.

Petrini, O. (1991). Fungal Endophytes of Tree Leaves. Microbial Ecology of Leaves, 1961, 179-180.

Porras-Alfaro, A., \& Bayman, P. (2011). Hidden Fungi, Emergent Properties: Endophytes and Microbiomes. Annual Review of Phytopathology, 49(1), 291-315. https://doi.org/10.1146/annurev-phyto-080508-081831

Rashmi, M., Js, K., \& Vv, S. (2019). A worldwide list of endophytic fungi with notes on ecology and diversity. Mycosphere, 10(1), 798-1079. 
591

592

593

594

595

596

597

598

599

600

601

602

603

604

605

606

607

608

609

610

611

612

613

614

615

616

617

618

619

620

621

622

623

624

625

626

627

628

https://doi.org/10.5943/mycosphere/10/1/19

Regato, P. (2001). The Mediterranean Forests - A Conservation Strategy. WWF-MedPO Ed., 1-30.

Rodriguez, R. J., White, J. F., Arnold, A. E., \& Redman, R. S. (2009). Fungal endophytes: Diversity and functional roles: Tansley review. New Phytologist, 182(2), 314-330. https://doi.org/10.1111/j.1469-8137.2009.02773.x

Rognes, T., Flouri, T., Nichols, B., Quince, C., \& Mahé, F. (2016). VSEARCH: A versatile open source tool for metagenomics. PeerJ, 2016(10), 0-22. https://doi.org/10.7717/peerj.2584

Saikkonen, K., Faeth, S. H., Helander, M., \& Sullivan, T. J. (1998). Fungal endophytes: A continuum of interactions with host plants. Annual Review of Ecology and Systematics, 29, 319-343. https://doi.org/10.1146/annurev.ecolsys.29.1.319

Saikkonen K, Saari S, Helander M (2010). Defensive mutualism between plants and endophytic fungi? Fungal Divers 41:101-113. https://doi.org/10.1007/s13225-010-0023-7

Schulz, B., \& Boyle, C. (2005). The endophytic continuum. Mycological Research, 109(6), 661-686. https://doi.org/10.1017/S095375620500273X

Sieber, T. N. (2007). Endophytic fungi in forest trees: are they mutualists? Fungal Biology Reviews, 21(2-3), 75-89. https://doi.org/10.1016/j.fbr.2007.05.004

Skaltsas, D. N., Badotti, F., Vaz, A. B. M., Silva, F. F. da, Gazis, R., Wurdack, K., Castlebury, L., Góes-Neto, A., \& Chaverri, P. (2019). Exploration of stem endophytic communities revealed developmental stage as one of the drivers of fungal endophytic community assemblages in two Amazonian hardwood genera. Scientific Reports, 9(1), 114. https://doi.org/10.1038/s41598-019-48943-2

Stone, J. K., Polishook, J. D., \& White, J. R. (2004). Endophytic fungi, In. Biodiversity of fungi, Inventory and Monitoring Methods, Eds. Mueller GM, Bills GF, Foster MS. Elsevier Academic Press: Burlington. MA, USA.

Sumbul, S., Aftab Ahmad, M., Asif, M., \& Akhtar, M. (2011). Myrtus communis Linn. - A review. Indian Journal of Natural Products and Resources, 2(4), 395-402.

Thomas, D. C., Vandegrift, R., Ludden, A., Carroll, G. C., \& Roy, B. A. (2016). Spatial Ecology of the Fungal Genus Xylaria in a Tropical Cloud Forest. Biotropica, 48(3), 381393. https://doi.org/10.1111/btp.12273

Thomas D, Vandegrift R, Roy BA, Hsieh H-M, Ju Y-M. 2019. Spatial patterns of fungal endophytes in a subtropical montane rainforest of northern Taiwan. Fungal Ecology 39:316-327. DOI 10.1016/j.funeco.2018.12.012.

Thomas, D. C., Vandegrift, \& Roy, B. A. (2020). An agent-based model of the foraging ascomycete hypothesis. Fungal Ecology, 47. https://doi.org/10.1016/j.funeco.2020.100963

Toju, H., Guimarães, P. R., Olesen, J. M., \& Thompson, J. N. (2014). Assembly of complex plant-fungus networks. Nature Communications, 5. https://doi.org/10.1038/ncomms6273 

B. S., Campbell, K., Costa, I. R., De-Carvalho, P. S., Faria, J. E. Q., Giaretta, A., Kooij, P. W., Lima, D. F., Mazine, F. F., Peguero, B., Prenner, G., Santos, M. F., Soewarto, J., Wingler, A., \& Lucas, E. J. (2017). Myrteae phylogeny, calibration, biogeography and diversification patterns: Increased understanding in the most species rich tribe of Myrtaceae. Molecular Phylogenetics and Evolution, 109, 113-137.

635 https://doi.org/10.1016/j.ympev.2017.01.002 G., Rosa, L. H., \& Rosa, C. A. (2012). Diversity and antimicrobial activity of fungal endophyte communities associated with plants of Brazilian savanna ecosystems. African Journal of Microbiology Research, 6(13), 3173-3185. https://doi.org/10.5897/ajmr11.1359 endophytes associated with three South American Myrtae (Myrtaceae) exhibit preferences in the colonization at leaf level. Fungal Biology, 118(3), 277-286. https://doi.org/10.1016/j.funbio.2013.11.010 Cunha, M. C., Soares, M. A., Santos, V. L., Oliveira, G., Chaverri, P., \& Góes-Neto, A. (2018). A multiscale study of fungal endophyte communities of the foliar endosphere of native rubber trees in Eastern Amazon. Scientific Reports, 8(1), 1-11.

651

652 https://doi.org/10.1038/s41598-018-34619-w (NGS) to uncover diversity of wood-decaying fungi in neotropical Atlantic forests. Phytotaxa, 295(1), 121. \& Rosa, C. A. (2014). Fungal endophyte b-diversity associated with Myrtaceae species in an Andean Patagonian forest. Fungal Ecology, 8(31), 28-36. https://doi.org/10.1016/j.funeco.2013.12.008

Vorholt, J. A. (2012). Microbial life in the phyllosphere. Nature Reviews Microbiology,

661 10(12), 828-840. https://doi.org/10.1038/nrmicro2910 sequencing of fungal ribosomal RNA genes for phylogenetics. PCR Protocols: A Guide to Methods and Applications, 18(1), 315-322.

664 and endophytic fungal community and network structures differ in a tropical mangrove ecosystem. Microbiome, 7(1), 1-15. https://doi.org/10.1186/s40168-019-0671-0 


\section{Figure 1}

Bipartite ecological network of Myrtus communis individuals and their foliar fungal endophytes.

The bipartite ecological network: green circles (nodes: tree set) represent Myrtus communis individuals (T1T11) (left), and blue circles (nodes: fungal set) represent putative fungal endophytes species (right). Interacting taxa are linked by lines (links), whose width is proportional to the number of interactions. 


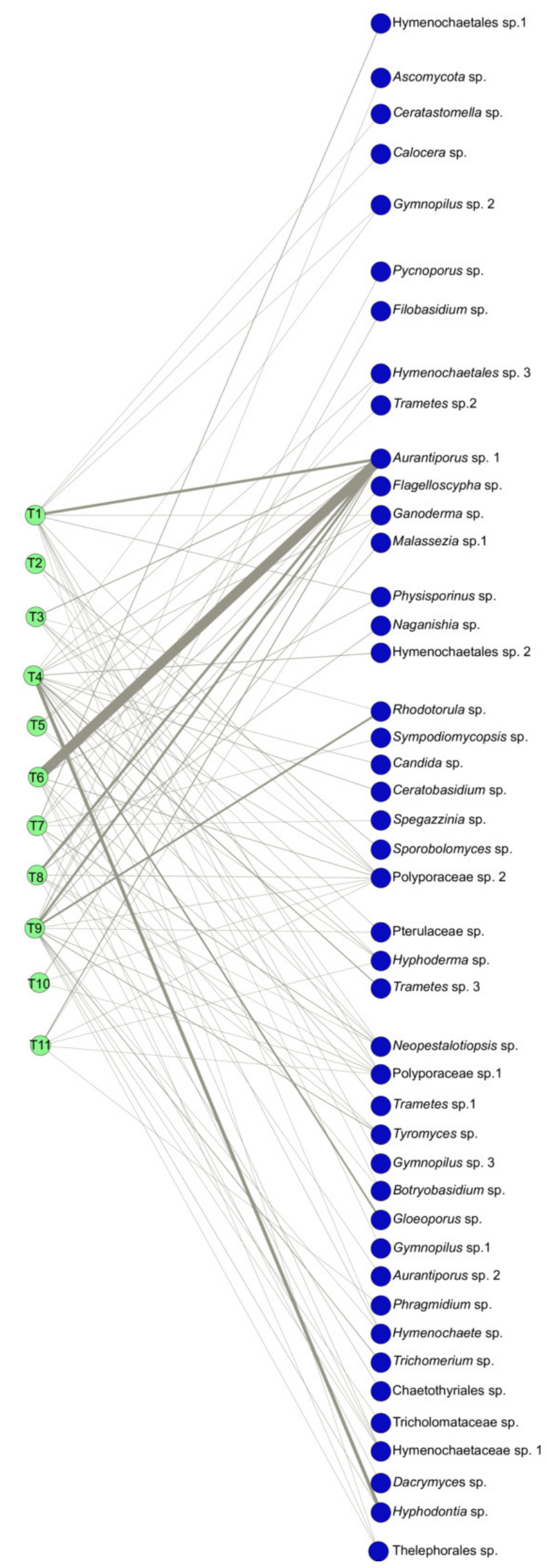

PeerJ reviewing PDF | (2020:01:45197:3:0:NEW 24 Oct 2020) 
Figure 2

Adjacency matrix of Myrtus communis individuals and their foliar fungal endophytes

The adjacency matrix of bipartite ecological network with shading representing number of interactions per link, normalized by z-score.

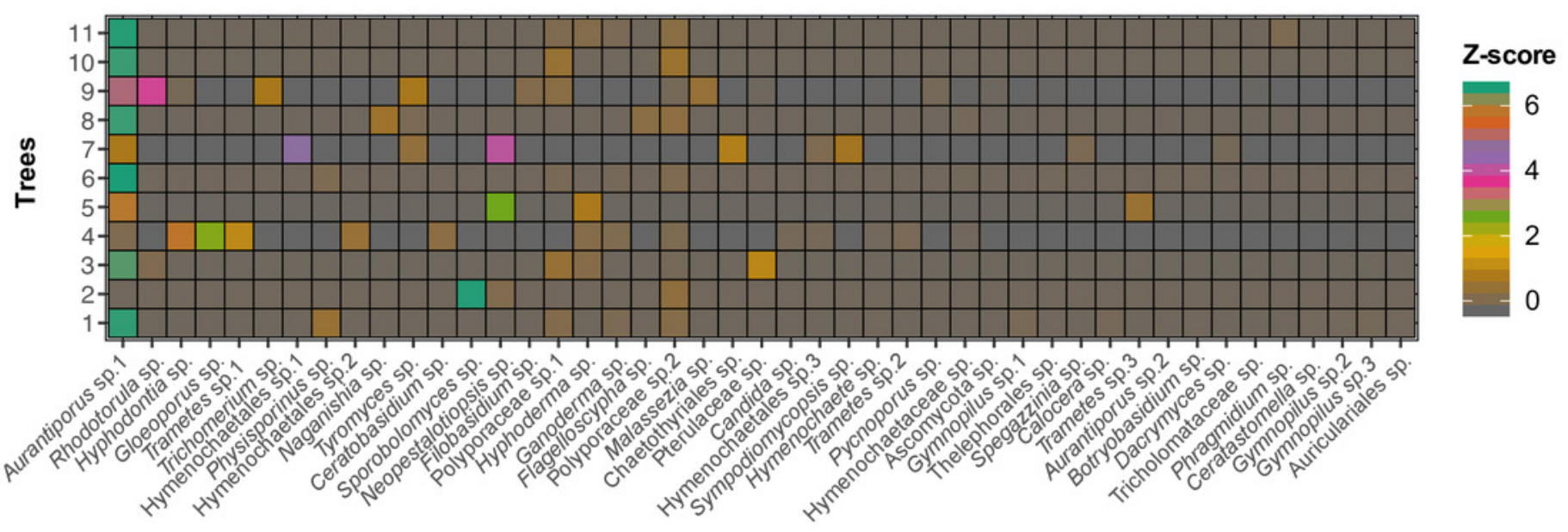

Putative Fungal Species 
Figure 3

Trophic modes of putative foliar fungal endophyte species

Venn diagram representing the joint and disjoint occurrences of putative endophytic fungal species of saprothrophic, pathotrophic, and symbiotrophic modes of nutrition in Myrtus communis trees. 


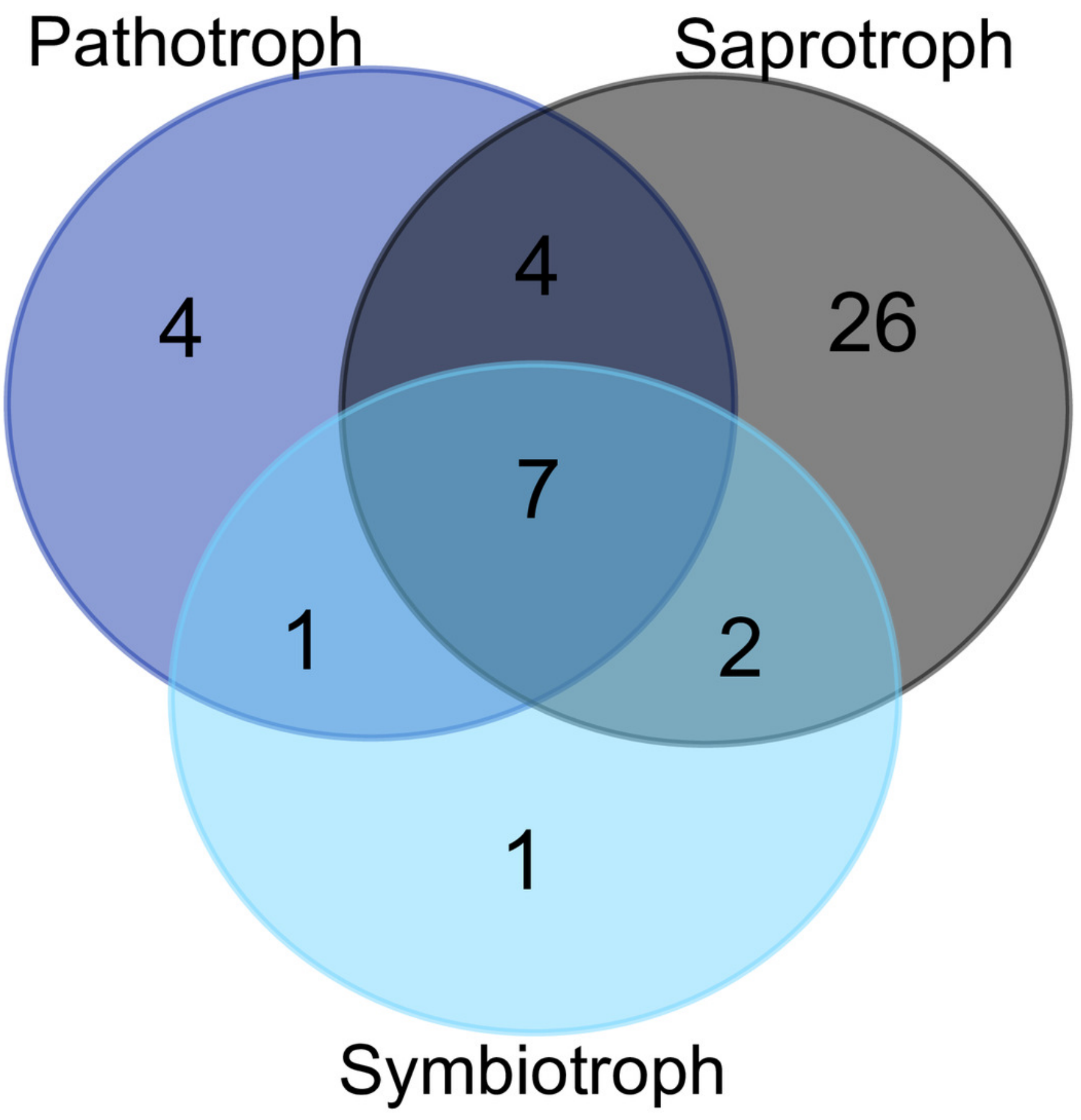




\section{Table 1 (on next page)}

Table 1. Summary of the number of reads in the metagenomic pipeline. 
1 Table 1. Summary of the number of reads in the metagenomic pipeline.

Steps of analysis

Merge paired-end sequence

Shorten and/or filter the sequences

Merge strictly identical sequences

Pre-clustering the fasta sequences

Detect chimeras without external references (i.e. de novo)

Detect chimeras present with reference sequences

xtract all non-chimeric, non-singleton sequences, dereplicated

(double-check) using Perl

Clustering
Number of reads

212,167

33,364

20,538

706

706

599

599

599 


\section{Table 2 (on next page)}

Putative fungal endophyte species in Myrtus communis individuals.

Complete taxonomic classification of putative fungal endophyte species in Myrtus communis individuals and their corresponding percentage coverage and identity. 
1 Table 2. Putative fungal endophyte species in Myrtus communis individuals.

\begin{tabular}{|c|c|c|c|c|c|c|c|c|}
\hline $\begin{array}{l}\text { Putative } \\
\text { Species }\end{array}$ & Phylum & Subphylum & Class & Order & Family & Genus & $\%$ Identity & \% Cover \\
\hline Ascomycota sp. & Ascomycota & undefined & undefined & undefined & undefined & undefined & 95.25 & 98 \\
\hline Aurantiporus sp. 1 & Basidiomycota & Agaricomycotina & $\begin{array}{l}\text { Agaricomycete } \\
\text { s } \\
\text { Agaricomycete }\end{array}$ & Polyporales & Meruliaceae & Aurantiporus & 99.38 & 100 \\
\hline Aurantiporus sp. 2 & Basidiomycota & Agaricomycotina & $\begin{array}{c}\mathrm{s} \\
\text { Agaricomycete }\end{array}$ & Polyporales & Meruliaceae & $\begin{array}{l}\text { Aurantiporus } \\
\text { Botryobasidi }\end{array}$ & 98.70 & 94 \\
\hline Botryobasidium sp. & Basidiomycota & Agaricomycotina & $\mathrm{s}$ & $\begin{array}{l}\text { Cantharellales } \\
\text { Dacrymycetale }\end{array}$ & Botryobasidiaceae & um & 96.90 & 96 \\
\hline Calocera sp. & Basidiomycota & $\begin{array}{l}\text { Agaricomycotina } \\
\text { Saccharomycotin }\end{array}$ & $\begin{array}{l}\text { Dacrymycetes } \\
\text { Saccharomycet }\end{array}$ & $\begin{array}{c}\mathrm{s} \\
\text { Saccharomycet }\end{array}$ & Dacrymycetaceae & Calocera & 97.15 & 100 \\
\hline Candida sp. & Ascomycota & & es & ales & Saccharomycetales & Candida & 98.71 & 97 \\
\hline Ceratastomella sp. & Ascomycota & Pezizomycotina & $\begin{array}{c}\text { Sordariomycet } \\
\text { es }\end{array}$ & Incertae sedis & $\begin{array}{c}\text { Barbatosphaeriacea } \\
\mathrm{e}\end{array}$ & $\begin{array}{c}\text { Ceratastomel } \\
\text { la }\end{array}$ & 98.17 & 96 \\
\hline Ceratobasidium sp. & Basidiomycota & Agaricomycotina & $\begin{array}{l}\text { Agaricomycete } \\
\mathrm{S}\end{array}$ & Cantharellales & Ceratobasidiaceae & $\begin{array}{l}\text { Ceratobasidi } \\
\text { um }\end{array}$ & 99.12 & 94 \\
\hline Chaetothyriales sp. & Ascomycota & Pezizomycotina & $\begin{array}{l}\text { Eurotiomycete } \\
\text { s }\end{array}$ & $\begin{array}{c}\text { Chaetothyriale } \\
\text { s }\end{array}$ & Chaetothyriales & undefined & 92.86 & 93 \\
\hline Dacrymyces sp. & Basidiomycota & Agaricomycotina & Dacrymycetes & $\begin{array}{c}\text { Dacrymycetale } \\
\mathrm{s}\end{array}$ & Dacrymycetaceae & Dacrymyces & 99.66 & 95 \\
\hline Filobasidium sp. & Basidiomycota & Agaricomycotina & $\begin{array}{c}\text { Tremellomycet } \\
\text { es }\end{array}$ & Filobasidiales & Filobasidiaceae & Filobasidium & 99.73 & 100 \\
\hline Flagelloscypha sp. & Basidiomycota & Agaricomycotina & $\begin{array}{l}\text { Agaricomycete } \\
\mathrm{s}\end{array}$ & Agaricales & Niaceae & $\begin{array}{l}\text { Flagelloscyp } \\
\text { ha }\end{array}$ & 99.19 & 95 \\
\hline Ganoderma sp. & Basidiomycota & Agaricomycotina & $\begin{array}{l}\text { Agaricomycete } \\
\mathrm{S}\end{array}$ & Polyporales & Polyporaceae & Ganoderma & 97.78 & 93 \\
\hline Gloeoporus sp. & Basidiomycota & Agaricomycotina & $\begin{array}{l}\text { Agaricomycete } \\
\text { s }\end{array}$ & Polyporales & Meruliaceae & Gloeoporus & 99.29 & 91 \\
\hline Gymnopilus sp. 1 & Basidiomycota & Agaricomycotina & $\begin{array}{l}\text { Agaricomycete } \\
\mathrm{S}\end{array}$ & Agaricales & Strophariaceae & Gymnopilus & 97.66 & 100 \\
\hline Gymnopilus sp. 2 & Basidiomycota & Agaricomycotina & $\begin{array}{l}\text { Agaricomycete } \\
\mathrm{S}\end{array}$ & Agaricales & Strophariaceae & Gymnopilus & 98.24 & 94 \\
\hline Gymnopilus sp. 3 & Basidiomycota & Agaricomycotina & $\begin{array}{l}\text { Agaricomycete } \\
\text { s }\end{array}$ & Agaricales & Strophariaceae & Gymnopilus & 98.25 & 100 \\
\hline $\begin{array}{l}\text { Hymenochaetaceae } \\
\text { sp. }\end{array}$ & Basidiomycota & Agaricomycotina & $\begin{array}{l}\text { Agaricomycete } \\
\text { s }\end{array}$ & $\begin{array}{c}\text { Hymenochaeta } \\
\text { les }\end{array}$ & Hymenochaetaceae & undefined & 95.38 & 100 \\
\hline $\begin{array}{l}\text { Hymenochaetales } \\
\text { sp. } 1\end{array}$ & Basidiomycota & Agaricomycotina & $\begin{array}{l}\text { Agaricomycete } \\
\mathrm{S}\end{array}$ & $\begin{array}{c}\text { Hymenochaeta } \\
\text { les }\end{array}$ & undefined & undefined & 95.67 & 98 \\
\hline $\begin{array}{l}\text { Hymenochaetales } \\
\text { sp. } 2\end{array}$ & Basidiomycota & Agaricomycotina & $\begin{array}{l}\text { Agaricomycete } \\
\text { s }\end{array}$ & $\begin{array}{c}\text { Hymenochaeta } \\
\text { les }\end{array}$ & undefined & undefined & 90.49 & 96 \\
\hline $\begin{array}{l}\text { Hymenochaetales } \\
\text { sp. } 3\end{array}$ & Basidiomycota & Agaricomycotina & $\begin{array}{l}\text { Agaricomycete } \\
\mathrm{s}\end{array}$ & $\begin{array}{c}\text { Hymenochaeta } \\
\text { les }\end{array}$ & undefined & undefined & 91.10 & 97 \\
\hline Hymenochaete sp. & Basidiomycota & Agaricomycotina & $\begin{array}{l}\text { Agaricomycete } \\
\text { s }\end{array}$ & $\begin{array}{c}\text { Hymenochaeta } \\
\text { les }\end{array}$ & Hymenochaetaceae & $\begin{array}{l}\text { Hymenochae } \\
\text { te }\end{array}$ & 99.37 & 97 \\
\hline Hyphoderma sp. & Basidiomycota & Agaricomycotina & $\begin{array}{l}\text { Agaricomycete } \\
\mathrm{S}\end{array}$ & Polyporales & Meruliaceae & Hyphoderma & 96.95 & 100 \\
\hline Hyphodontia sp. & Basidiomycota & Agaricomycotina & $\begin{array}{l}\text { Agaricomycete } \\
\text { s }\end{array}$ & $\begin{array}{c}\text { Hymenochaeta } \\
\text { les }\end{array}$ & Schizoporaceae & Hyphodontia & 99.68 & 96 \\
\hline Malassezia sp. 1 & Basidiomycota & $\begin{array}{c}\text { Ustilaginomycoti } \\
\text { na }\end{array}$ & $\begin{array}{l}\text { Malasseziomy } \\
\text { cetes }\end{array}$ & Malasseziales & Malasseziaceae & Malassezia & 99.02 & 100 \\
\hline Naganishia sp. & Basidiomycota & Agaricomycotina & $\begin{array}{c}\text { Tremellomycet } \\
\text { es }\end{array}$ & Tremellales & Tremellaceae & Naganishia & 99.72 & 100 \\
\hline $\begin{array}{l}\text { Neopestalotiopsis } \\
\text { sp. }\end{array}$ & Ascomycota & Pezizomycotina & $\begin{array}{c}\text { Sordariomycet } \\
\text { es }\end{array}$ & Xylariales & Amphisphaeriaceae & $\begin{array}{l}\text { Neopestaloti } \\
\text { opsis }\end{array}$ & 98.58 & 90 \\
\hline Phragmidium sp. & Basidiomycota & $\begin{array}{c}\text { Pucciniomycotin } \\
\mathrm{a}\end{array}$ & $\begin{array}{l}\text { Pucciniomycet } \\
\text { es }\end{array}$ & Pucciniales & Phragmidiaceae & $\underset{\mathrm{m}}{\text { Phragmidiu }}$ & 97.08 & 98 \\
\hline Physisporinus sp. & Basidiomycota & Agaricomycotina & $\begin{array}{l}\text { Agaricomycete } \\
\mathrm{S}\end{array}$ & Polyporales & Meripilaceae & $\begin{array}{c}\text { Physisporinu } \\
\text { S }\end{array}$ & 98.51 & 100 \\
\hline Polyporaceae sp. 1 & Basidiomycota & Agaricomycotina & $\begin{array}{l}\text { Agaricomycete } \\
\text { s }\end{array}$ & Polyporales & Polyporaceae & undefined & 95.04 & 94 \\
\hline Polyporaceae sp. 2 & Basidiomycota & Agaricomycotina & $\begin{array}{l}\text { Agaricomycete } \\
\text { s }\end{array}$ & Polyporales & Polyporaceae & undefined & 95.29 & 94 \\
\hline Pterulaceae sp. & Basidiomycota & Agaricomycotina & $\begin{array}{l}\text { Agaricomycete } \\
\text { s }\end{array}$ & Agaricales & Pterulaceae & undefined & 96.17 & 94 \\
\hline
\end{tabular}




\begin{tabular}{|c|c|c|c|c|c|c|c|c|}
\hline Pycnoporus sp. & Basidiomycota & Agaricomycotina & $\begin{array}{l}\text { Agaricomycete } \\
\text { s }\end{array}$ & Polyporales & Polyporaceae & Pycnoporus & 99.09 & 100 \\
\hline Rhodotorula sp. & Basidiomycota & $\begin{array}{c}\text { Pucciniomycotin } \\
\text { a }\end{array}$ & $\begin{array}{l}\text { Microbotryom } \\
\text { ycetes }\end{array}$ & $\begin{array}{l}\text { Sporidiobolale } \\
\text { s }\end{array}$ & Sporidiobolaceae & Rhodotorula & 99.43 & 100 \\
\hline Spegazzinia sp. & Ascomycota & Pezizomycotina & $\begin{array}{l}\text { Dothidiomycet } \\
\text { es }\end{array}$ & Pleosporales & $\begin{array}{l}\text { Didymosphaeriacea } \\
\mathrm{e}\end{array}$ & Spegazzinia & 97.56 & 94 \\
\hline $\begin{array}{l}\text { Sporobolomyces } \\
\text { sp. }\end{array}$ & Basidiomycota & $\begin{array}{l}\text { Pucciniomycotin } \\
\text { a }\end{array}$ & $\begin{array}{l}\text { Microbotryom } \\
\text { ycetes }\end{array}$ & $\begin{array}{l}\text { Sporidiobolale } \\
\mathrm{s}\end{array}$ & Sporidiobolaceae & $\begin{array}{l}\text { Sporobolom } \\
\text { yces }\end{array}$ & 99.12 & 100 \\
\hline $\begin{array}{l}\text { Sympodiomycopsis } \\
\text { sp. }\end{array}$ & Basidiomycota & $\begin{array}{l}\text { Ustilaginomycoti } \\
\text { na }\end{array}$ & $\begin{array}{l}\text { Exobasidiomy } \\
\text { cetes }\end{array}$ & $\begin{array}{l}\text { Microstromatal } \\
\text { es }\end{array}$ & Microstromataceae & $\begin{array}{l}\text { Sympodiom } \\
\text { ycopsis }\end{array}$ & 99.71 & 97 \\
\hline Thelephorales sp. & Basidiomycota & Agaricomycotina & $\begin{array}{l}\text { Agaricomycete } \\
\text { s }\end{array}$ & Thelephorales & unidentified & unidentified & 93.41 & 100 \\
\hline Trametes sp. 1 & Basidiomycota & Agaricomycotina & $\begin{array}{l}\text { Agaricomycete } \\
\text { s }\end{array}$ & Polyporales & Polyporaceae & Trametes & 98.77 & 100 \\
\hline Trametes sp. 2 & Basidiomycota & Agaricomycotina & $\begin{array}{l}\text { Agaricomycete } \\
\text { s }\end{array}$ & Polyporales & Polyporaceae & Trametes & 99.04 & 96 \\
\hline Trametes sp. 3 & Basidiomycota & Agaricomycotina & $\begin{array}{l}\text { Agaricomycete } \\
\text { s }\end{array}$ & Polyporales & Polyporaceae & Trametes & 97.84 & 100 \\
\hline $\begin{array}{c}\text { Tricholomataceae } \\
\text { sp. }\end{array}$ & Basidiomycota & Agaricomycotina & $\begin{array}{l}\text { Agaricomycete } \\
\text { s }\end{array}$ & Agaricales & Tricholomataceae & undefined & 85.68 & 94 \\
\hline Trichomerium sp. & Ascomycota & Pezizomycotina & $\begin{array}{l}\text { Eurotiomycete } \\
\mathrm{s}\end{array}$ & $\begin{array}{c}\text { Chaetothyriale } \\
\text { s }\end{array}$ & Trichomeriaceae & $\begin{array}{l}\text { Trichomeriu } \\
\mathrm{m}\end{array}$ & 97.89 & 100 \\
\hline Tyromyces sp. & Basidiomycota & Agaricomycotina & $\begin{array}{l}\text { Agaricomycete } \\
\text { s }\end{array}$ & Polyporales & Polyporaceae & Tyromyces & 96.98 & 100 \\
\hline
\end{tabular}

2 
Table 3 (on next page)

Types and values of network-level indexes. 
1 Table 3. Types and values of network-level indexes.

\begin{tabular}{cc} 
INDEX & VALUE \\
\hline connectance & $\mathbf{0 . 1 8 9 8 9 8 9 9}$ \\
web asymmetry & $\mathbf{0 . 6 0 7 1 4 2 8 6}$ \\
links per taxa & $\mathbf{1 . 6 7 8 5 7 1 4 3}$ \\
nestedness & 21.5741105 \\
NODF & 29.5555935 \\
weighted nestedness & 0.42947246 \\
weighted NODF & $\mathbf{1 5 . 2 7 2 9 9 3 1}$ \\
interaction strength asymmetry & 0.35324107 \\
linkage density & $\mathbf{3 . 4 7 7 3 1 9 3 1}$ \\
weighted connectance & $\mathbf{0 . 0 6 2 0 9 4 9 9}$ \\
H2 & $\mathbf{0 . 6 1 7 2 8 6 8 2}$ \\
Modularity (Q) & $\mathbf{0 . 4 4 0 7 5 4}$ \\
number.of.taxa.HL & $\mathbf{4 4}$ \\
number.of.taxa.LL & $\mathbf{1 1}$ \\
mean.number.of.shared.partners.HL & 0.47777778 \\
mean.number.of.shared.partners.LL & 2.65454545 \\
weighted.cluster.coefficient.HL & 0,85253503 \\
weighted.cluster.coefficient.LL & 0,33579411 \\
niche.overlap.HL & $\mathbf{0 , 1 8 5 7 8 4 1 5}$ \\
niche.overlap.LL & $\mathbf{0 , 4 7 8 8 7 0 2 3}$ \\
C.score.HL & $\mathbf{0 . 6 4 7 8 5 2 7 3}$ \\
C.score.LL & 0.39092274 \\
\hline
\end{tabular}


Table 4 (on next page)

Types and values of higher trophic level indexes 
1 Table 4: Types and values of higher trophic level indexes.

\begin{tabular}{|c|c|c|c|c|c|}
\hline Taxon & Degree & $\begin{array}{c}\text { Normalized } \\
\text { degree }\end{array}$ & $\begin{array}{l}\text { Species } \\
\text { strength }\end{array}$ & $\begin{array}{c}\text { Weighted } \\
\text { betweenness }\end{array}$ & \\
\hline Ascomycota & 1 & 0.090909091 & 0.006877579 & 0 & \\
\hline Aurantiporus sp.1 & 10 & 0.909090909 & 6.000985121 & 0.69445883 & \\
\hline Aurantiporus sp.2 & 1 & 0.090909091 & 0.001449275 & 0 & \\
\hline Auriculariales & 1 & 0.090909091 & 0.005148005 & 0 & \\
\hline Botryobasidium & 2 & 0.181818182 & 0.004023278 & 0 & \\
\hline Calocera & 1 & 0.090909091 & 0.01029601 & 0 & \\
\hline Candida & 1 & 0.090909091 & 0.01346046 & 0 & \\
\hline Ceratastomella & 1 & 0.090909091 & 0.005148005 & 0 & \\
\hline Ceratobasidium & 1 & 0.090909091 & 0.037016265 & 0 & \\
\hline Chaetothyriales & 1 & 0.090909091 & 0.084175084 & 0 & \\
\hline Dacrymyces & 1 & 0.090909091 & 0.013468013 & 0 & \\
\hline Filobasidium & 1 & 0.090909091 & 0.027510316 & 0 & \\
\hline Flagelloscypha & 1 & 0.090909091 & 0.044414536 & 0 & \\
\hline Ganoderma & 4 & 0.363636364 & 0.067952092 & 0 & \\
\hline Gloeoporus & 1 & 0.090909091 & 0.198541784 & 0 & \\
\hline Gymnopilus sp.1 & 1 & 0.090909091 & 0.012870013 & 0 & \\
\hline Gymnopilus sp.2 & 1 & 0.090909091 & 0.005148005 & 0 & \\
\hline Gymnopilus sp.3 & 2 & 0.181818182 & 0.008843713 & 0 & 1.75 \\
\hline Hymenochaetaceae sp.1 & 4 & 0.363636364 & 0.021985178 & 0 & \\
\hline Hymenochaetales sp.1 & 1 & 0.090909091 & 0.36026936 & 0 & \\
\hline Hymenochaetales sp.2 & 1 & 0.090909091 & 0.049915872 & 0 & \\
\hline Hymenochaetales sp. 3 & 2 & 0.181818182 & 0.038151188 & 0 & \\
\hline Hymenochaete & 3 & 0.272727273 & 0.017014422 & 0 & \\
\hline Hyphoderma & 4 & 0.363636364 & 0.19456545 & 0 & 2.4 \\
\hline Hyphodontia & 2 & 0.181818182 & 0.460574461 & 0.163127913 & 1.13 \\
\hline Malassezia & 1 & 0.090909091 & 0.049518569 & 0 & \\
\hline Naganishia & 1 & 0.090909091 & 0.083445491 & 0 & \\
\hline Neopestalotiopsis & 5 & 0.454545455 & 0.612542425 & 0.100983946 & \\
\hline Phragmidium & 1 & 0.090909091 & 0.020100503 & 0 & \\
\hline Physisporinus & 2 & 0.181818182 & 0.090150243 & 0 & 1.99 \\
\hline Polyporaceae sp.1 & 7 & 0.636363636 & 0.244426366 & 0 & \\
\hline Polyporaceae sp.2 & 9 & 0.818181818 & 0.342257352 & 0.041429311 & 6.26 \\
\hline Pterulaceae & 2 & 0.181818182 & 0.139566226 & 0 & 1.86 \\
\hline Pycnoporus & 1 & 0.090909091 & 0.014442916 & 0 & \\
\hline Rhodotorula & 2 & 0.181818182 & 0.322363942 & 0 & 1.06 \\
\hline Spegazzinia & 1 & 0.090909091 & 0.02020202 & 0 & \\
\hline Sporobolomyces & 1 & 0.090909091 & 0.911764706 & 0 & \\
\hline
\end{tabular}




$\begin{array}{clcccr}\text { Sympodiomycopsis } & 1 & 0.090909091 & 0.067340067 & 0 & 1 \\ \text { Thelephorales } & 3 & 0.272727273 & 0.006123431 & 0 & 2.5864 \\ \text { Trametes sp.1 } & 1 & 0.090909091 & 0.096466629 & 0 & 1 \\ \text { Trametes sp.2 } & 1 & 0.090909091 & 0.0625 & 0 & 1 \\ \text { Trametes sp.3 } & 1 & 0.090909091 & 0.018508132 & 0 & 1 \\ \text { Tricholomataceae } & 1 & 0.090909091 & 0.002751032 & 0 & 1.8581 \\ \text { Trichomerium } & 1 & 0.090909091 & 0.072902338 & 0 & 0 \\ \text { Tyromyces } & 3 & 0.272727273 & 0.132824122 & & \end{array}$

2 


\section{Table 5 (on next page)}

Types and values of lower trophic level indexes. 
1 Table 5: Types and values of lower trophic level indexes.

\begin{tabular}{ccccccr}
\hline Tree & Degree & $\begin{array}{c}\text { Normalized } \\
\text { degree }\end{array}$ & $\begin{array}{c}\text { Species } \\
\text { strength }\end{array}$ & $\begin{array}{c}\text { Weighted } \\
\text { betweenness }\end{array}$ & $\begin{array}{c}\text { Effective } \\
\text { partners }\end{array}$ & $\begin{array}{r}\text { Proportio } \\
\text { generalit }\end{array}$ \\
\hline T1 & 14 & 0.31111111 & 7.48918425 & 0 & 2.57524028 & 0.3689437 \\
T2 & 3 & 0.06666667 & 1.0355272 & 0 & 1.42560863 & 0.2042408 \\
T3 & 6 & 0.13333333 & 0.9258364 & 0 & 2.53708048 & 0.363476 \\
T4 & 16 & 0.35555556 & 10.8434777 & 0.15686275 & 6.44529054 & 0.9233893 \\
T5 & 4 & 0.08888889 & 1.23405498 & 0 & 2.89831062 & 0.4152286 \\
T6 & 9 & 0.2 & 4.34350996 & 0.15686275 & 1.4668374 & 0.2101475 \\
T7 & 9 & 0.2 & 6.11079302 & 0.17647059 & 5.34577583 & 0.7658665 \\
T8 & 8 & 0.17777778 & 2.56345887 & 0.23529412 & 2.24831695 & 0.3221068 \\
T9 & 16 & 0.35555556 & 9.09088067 & 0.2745098 & 5.94181194 & 0.8512581 \\
T10 & 3 & 0.06666667 & 0.11981709 & 0 & 1.7172954 & 0.2460296 \\
T11 & 6 & 0.13333333 & 1.24345983 & 0 & 1.86340415 & 0.2669619 \\
\hline
\end{tabular}


Table 6(on next page)

Ecological guilds of putative fungal endophyte species. 
1 Table 6. Ecological guilds of putative fungal endophyte species.

\begin{tabular}{|c|c|c|}
\hline Putative Species & Trophic Mode & Guild \\
\hline Ascomycota sp. & $\begin{array}{l}\text { Pathotroph-Saprotroph- } \\
\text { Symbiotroph }\end{array}$ & All possible guilds \\
\hline Aurantiporus sp. 1 & Saprotroph & Wood Saprotroph \\
\hline Aurantiporus sp. 2 & Saprotroph & Wood Saprotroph \\
\hline Botryobasidium sp. & Saprotroph & Wood Saprotroph \\
\hline Calocera sp. & Saprotroph & undefined Saprotroph \\
\hline Candida sp. & Saprotroph & Wood Saprotroph \\
\hline Ceratastomella sp. & $\begin{array}{l}\text { Pathotroph-Saprotroph- } \\
\text { Symbiotroph } \\
\text { Pathotroph }\end{array}$ & $\begin{array}{c}\text { Animal Pathogen-Endosymbiont- } \\
\text { undefined Saprotroph } \\
\text { Plant Pathogen }\end{array}$ \\
\hline Chaetothyriales sp. & $\begin{array}{l}\text { Pathotroph-Saprotroph- } \\
\text { Symbiotroph }\end{array}$ & $\begin{array}{c}\text { Endomycorrhizal-Plant } \\
\text { Pathogen-undefined Saprotroph }\end{array}$ \\
\hline Dacrymyces sp. & Pathothroph & $\begin{array}{l}\text { Endosymbiont-Plant Pathogen- } \\
\text { undefined Saprotroph }\end{array}$ \\
\hline Filobasidium sp. & Saprotroph & Wood Saprotroph \\
\hline Flagelloscypha sp. & Saprotroph & undefined Saprotroph \\
\hline Ganoderma sp. & Saprotroph & undefined Saprotroph \\
\hline Gloeoporus sp. & Pathotroph-Saprotroph & $\begin{array}{l}\text { Plant Pathogen-Wood } \\
\text { Saprotroph }\end{array}$ \\
\hline Gymnopilus sp. 1 & Saprotroph & Wood Saprotroph \\
\hline Gymnopilus sp. 2 & Saprotroph & Wood Saprotroph \\
\hline Gymnopilus sp. 3 & Saprotroph & Wood Saprotroph \\
\hline Hymenochaetaceae sp. & Saprotroph & Wood Saprotroph \\
\hline Hymenochaetales sp. 1 & Saprotroph-Symbiotroph & $\begin{array}{l}\text { Ectomycorrhizal-Wood } \\
\text { Saprotroph }\end{array}$ \\
\hline Hymenochaetales sp. 2 & $\begin{array}{c}\text { Pathotroph-Saprotroph- } \\
\text { Symbiotroph }\end{array}$ & $\begin{array}{l}\text { Ectomycorrhizal-Wood } \\
\text { Saprotroph-Plant Pathogen }\end{array}$ \\
\hline Hymenochaetales sp. 3 & $\begin{array}{l}\text { Pathotroph-Saprotroph- } \\
\text { Symbiotroph }\end{array}$ & $\begin{array}{l}\text { Ectomycorrhizal-Wood } \\
\text { Saprotroph-Plant Pathogen }\end{array}$ \\
\hline Hymenochaete sp. & $\begin{array}{l}\text { Pathotroph-Saprotroph- } \\
\text { Symbiotroph } \\
\text { Saprotroph }\end{array}$ & $\begin{array}{l}\text { Ectomycorrhizal-Wood } \\
\text { Saprotroph-Plant Pathogen } \\
\text { undefined Saprotroph }\end{array}$ \\
\hline Hyphodontia sp. & Saprotroph & undefined Saprotroph \\
\hline Malassezia sp. 1 & Saprotroph & undefined Saprotroph \\
\hline Naganishia sp. & Pathotroph-Saprotroph & $\begin{array}{l}\text { Animal Pathogen-undefined } \\
\text { Saprotroph }\end{array}$ \\
\hline Neopestalotiopsis sp. & $\begin{array}{l}\text { Pathotroph-Saprotroph- } \\
\text { Symbiotroph }\end{array}$ & $\begin{array}{l}\text { Animal Pathogen-Endophyte- } \\
\text { Epiphyte-undefined Saprotroph }\end{array}$ \\
\hline Phragmidium sp. & Pathotroph & Plant Pathogen \\
\hline Physisporinus sp. & Saprotroph & undefined Saprotroph \\
\hline Polyporaceae sp. 1 & Saprotroph & Wood Saprotroph \\
\hline Polyporaceae sp. 2 & Saprotroph & Wood Saprotroph \\
\hline Pterulaceae sp. & Saprotroph & Wood Saprotroph \\
\hline Pycnoporus sp. & Saprotroph & Wood Saprotroph \\
\hline
\end{tabular}


Rhodotorula sp.

Spegazzinia sp.

Sporobolomyces sp.

Sympodiomycopsis sp.

Thelephorales sp.

Trametes sp. 1

Trametes sp. 2

Trametes sp. 3

Tricholomataceae sp.

Trichomerium sp.

Tyromyces sp.
Saprotroph

Pathotroph-Saprotroph

Saprotroph

Pathotroph-Saprotroph

Pathotroph

Symbiotroph-Saprothroph

Saprotroph

Saprotroph

Saprotroph

Pathotroph-Symbiotroph

Symbiotroph
Wood Saprotroph

Animal Endosymbiont-Animal

Pathogen-Endophyte-Plant

Pathogen-undefined Saprotroph undefined Saprotroph

Fungal Parasite-Litter Saprotroph Plant Pathogen

Ectosymbiont-Wood Saprotroph

Wood Saprotroph

Wood Saprotroph

Wood Saprotroph

Ectomycorrhizal-Fungal Parasite

Endophyte 